Niepełnosprawność. Dyskursy pedagogiki specjalnej

Nr 32/2018

Disability. Discourses of special education

No. 32/2018

\author{
Sławomir Olszewski, Katarzyna Parys \\ Uniwersytet Pedagogiczny w Krakowie
}

\title{
Wektory zmian zachodzących w polskiej pedagogice specjalnej ${ }^{1}$
}

\begin{abstract}
Artykuł zawiera analizę przemian zachodzących w polskiej pedagogice specjalnej w trzech zasadniczych obszarach: zakresie oddziaływań pedagogiki specjalnej wyrażającym się w systematyce, podmiocie i przedmiocie tych działań, a także w podejściu badawczym oraz terminologii, jaką posługuje się pedagogika specjalna. žródłem opisanych zjawisk są przeobrażenia zachodzące w podejściu do niepełnosprawności i do osób z niepełnosprawnością.
\end{abstract}

Słowa kluczowe: pedagogika specjalna, zakres oddziaływań pedagogiki specjalnej, podejście badawcze, terminologia

\section{Vectors of changes taking place in Polish special pedagogy}

The article contains an analysis of transformations that emerged in Polish special pedagogy in three basic areas: the scope of impacts of special pedagogy being expressed in the systematics, the subject and the object of such measures as well as in the research approach and the terminology employed by special pedagogy. The transformations in the approach to disability and people with disabilities are described as the sources of described phenomena.

Keywords: special pedagogy, the scope of impacts of special pedagogy, research approach, terminology

\section{Wprowadzenie - zasadność refleksji nad zmianami w pedagogice specjalnej}

Zmiany mogą być twórcze i pożyteczne, ale również niebezpieczne dla tożsamości dyscypliny. Ich blokowanie, przeciwstawianie się im, zamykanie na zmiany może prowadzić do stagnacji i niedopasowania względem wymogów rzeczywi-

1 Artykuł stanowi poszerzoną wersję tekstu opublikowanego w obcojęzycznej monografii zbiorowej Parys, Olszewski (2018), Quo vadis, special pedagogy? Reflections in the context of the Polish experience [w:] Teória a praxeológia výchovnej a komplexnej rehabilitácie. Zbornik vedeckých príspevkov, T. Harčaríková, J. Lopúchová (red.), Wydawnictwo MSD, Brno, s. 294-307. 
stości, rozmijania się z nią. Należy jednak przy tym pamiętać, iż nie każda zmiana oznacza postęp. Często nie tylko wprowadzanie zmian, ale i opór wobec nich może sprzyjać rozwojowi dyscypliny. Konieczne jest zatem refleksyjne i krytyczne podejście do zachodzących przeobrażeń, uwzględnianie celu i powodu ich wprowadzania oraz sposobów i kontekstu ich realizacji.

Pytanie o to, jak zmienia się oraz dokąd zmierza pedagogika specjalna niejednokrotnie było stawiane $w$ polskiej literaturze naukowej, czy to $w$ odniesieniu do założeń znajdujących zastosowanie w praktyce pedagogicznej: wychowaniu, kształceniu specjalnym, przygotowaniu pedagoga specjalnego do pracy [Pilecka, Pilecki 1993: 26-37; Kopeć 2004: 86-92; Pańczyk 2004: 13-17; Zaorska 2011: 4-9 i n.), czy na kanwie rozważań dotyczących kondycji pedagogiki specjalnej i jej tożsamości jako nauki [Dykcik 1999: 21-43; Krause 2009: 9-24; Krause 2010; Sadowska 2004: 80-85; Sadowska 2010: 221-232; Sadowska 2012: 260-268; Sadowska 2017: 24-37 i n.]. Przywołani autorzy nie ograniczają się do opisu zachodzących zmian, ale także stawiają pytania o zasadność wskazywanych przeobrażeń, formułują refleksje dotyczące ich słuszności. Czasem wyrażają niepokój o konsekwencje przemian, a także podkreślają konieczność podejmowania debat umożliwiających twórczą wymianę myśli. Podstawą przemyśleń i prowadzonych dyskusji powinna być analiza kierunku, dynamiki przeobrażeń oraz ich uwarunkowań. Ten sposób postępowania daje możność kontrolowania przemian, poprzez podejmowanie działań mających za zadanie wzmacnianie pozytywnych tendencji rozwojowych oraz niwelowanie potencjalnych zagrożeń. Śledząc i rozpatrując tendencje uwidaczniające się w zachodzących zmianach można bowiem przewidywać, a nawet $\mathrm{w}$ przemyślany sposób projektować rozwój dyscypliny, gdyż „każde jutro ma swoje tu i teraz” [Kopeć 2004: 86].

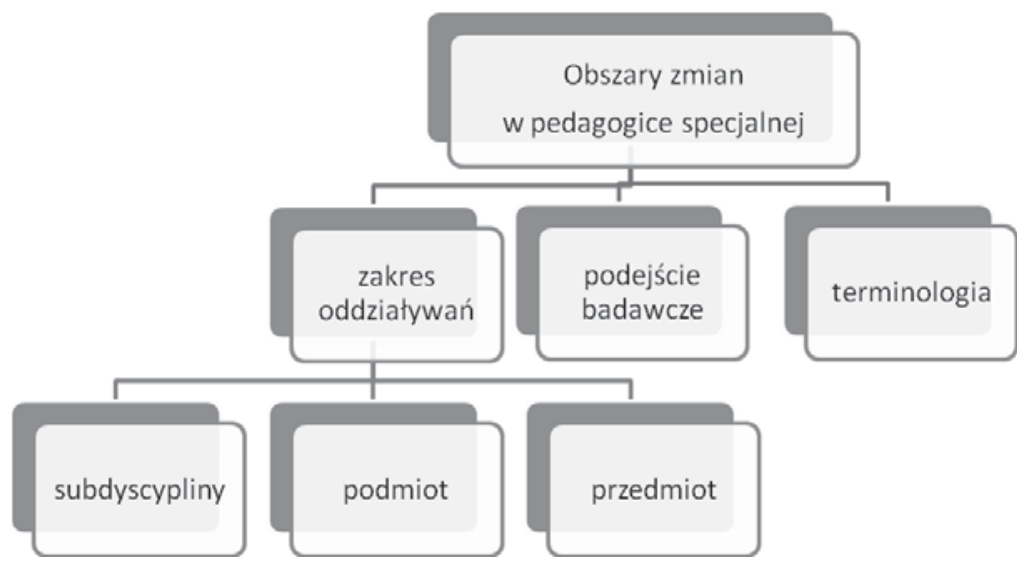

Schemat 1. Obszary zmian ujawniających się w polskiej pedagogice specjalnej žródło: Opracowanie własne. 
Dążąc do uporządkowania przeobrażeń dokonujących się na gruncie polskiej pedagogiki specjalnej, próbując wskazać najbardziej charakterystyczne dla tych zmian tendencje, wyodrębniliśmy trzy główne obszary zmian: 1) zakres oddziaływań pedagogiki specjalnej, 2) podejście badawcze, 3) terminologia, jaką posługuje się pedagogika specjalna (schemat 1 ).

\section{Zmiany dotyczące zakresu oddziaływań pedagogiki specjalnej}

Jednym ze sposobów opisania zakresu oddziaływań pedagogiki specjalnej jest odwołanie się do jej struktury wewnętrznej (subdysycpliny). Innym rozwiązaniem, pozwalającym ustalić zakres tej nauki, jest określenie podmiotu i przedmiotu, uwzględnianych zarówno w dociekaniach badawczych, jak i rozwiązaniach praktycznych. Odwołując się do trzech wymienionych elementów (subdyscypliny, podmiot, przedmiot pedagogiki specjalnej) poddamy analizie zmiany uwidoczniające się $w$ zakresie oddziaływań pedagogiki specjalnej.

Kierunki zmian dotyczących wyodrębnianych w pedagogice specjalnej subdyscyplin są następujące:

- Od klasycznych subdyscyplin: oligofrenopedagogika, surdopedagogika, tyflopedagogika, pedagogika terapeutyczna, pedagogika resocjalizacyjna [Lipkowski 1981: 7], wyróżnionych z uwagi na podstawowe rodzaje niepełnosprawności do wprowadzania nowych działów, skutkującego poszerzaniem zbioru subdyscyplin [por. Dykcikk 2005]. Powodem zwiększania się liczby działów jest wyodrębnianie nowych, wcześniej nie rozpoznawanych rodzajów niepełnosprawności. Subdyscypliny pedagogiki specjalnej, które powstały w wyniku tych procesów to na przykład pedagogika osób z autyzmem i zespołami psychozopodobnymi, pedagogika osób z niepetnosprawnościami sprzężonymi. Inną przyczyną poszerzania zbioru działów pedagogiki specjalnej jest objęcie uwagą zjawisk wykraczających poza granice niepełnosprawności, co skutkuje pojawianiem się subdyscyplin wiążących się ze specjalnymi potrzebami edukacyjnymi, czy zagrożeniem niepełnosprawnością (np. tanatopedagogika, pedagogika osób z trudnościami w uczeniu się, pedagogika dzieci zdolnych i uzdolnionych, pedagogika osób odmiennych somatycz$\left.n i e^{2}\right)$. Nie zawsze jednak ich pojawianie się zyskuje powszechną aprobatę. Nie wszystkie też uwidaczniają się w praktyce rehabilitacyjnej. Ponadto zamyka-

2 Wśród opracowań, w których uwzględnia się istnienie tych subdyscyplin można wymienić następujące publikacje: J. Binnebesel, Tanatopedagogika w doświadczeniu wielowymiarowości człowieka i śmierci, Wydawnictwo Adam Marszałek, Torun, 2013; W. Pilecka, Pedagogika osób z trudnościami w uczeniu się [w:] Pedagogika specjalna, W. Dykcik (red.), Wydawnictwo UAM, Poznań, 2005; E. Piotrowski, Pedagogika dzieci zdolnych i uzdolnionych [w:] Pedagogika specjalna, W. Dykcik (red.), Wydawnictwo UAM, Poznań, 2005; B. Jugowar, Pedagogika osób odmiennych somatycznie [w:] Pedagogika specjalna, W. Dykcik (red.), Wydawnictwo UAM, Poznań, 2005. 
nie niektórych działów, np. pedagogiki dzieci zdolnych i uzdolnionych w ramach pedagogiki specjalnej budzi wątpliwości, gdyż badacze zajmujący się tą problematyką nie samoidentyfikują się jako reprezentanci pedagogiki specjalnej, „[z]aplecze koncepcyjne, do którego mogą się odwoływać we własnych badaniach, postrzegają poza obszarem pedagogiki specjalnej" [Sadowska 2017: 32]. Pojawia się pytanie, czy wyodrębnianie kolejnych subdyscyplin jest zjawiskiem korzystnym dla pedagogiki specjalnej? Trudno o jednoznaczną odpowiedź w tym zakresie. Wydaje się, że działania tego rodzaju mogą jedynie pozornie wskazywać na rozwój dyscypliny, wszak dołączanie kolejnych kategorii osób lub zaburzeń nie musi prowadzić do rozszerzenia obszaru dociekań i uchwycenia całości aktualnych problemów naukowo-badawczych pedagogiki specjalnej [Dykcik 1999: 29].

- Od znacznej niezależności subdyscyplin do ich scalania, lączenia. Zjawisko to warunkowane jest tendencjami integracyjnymi obecnymi zarówno $\mathrm{w}$ teorii, jak i praktyce pedagogicznej. W obrębie poszczególnych subdyscyplin poza czynnikami swoistymi ujawniają się elementy wspólne, widoczne jest bowiem podobieństwo problemów i proponowanych rozwiązań, a także zasad postępowania. Tym samym budowane są nadrzędne, nadające kierunek działaniom, koncepcje wzbogacające zasoby ogólnej pedagogiki specjalnej. Równolegle tendencje scalające wymuszane są potrzebami praktyki. Przykładowo, coraz bardziej powszechnym zjawiskiem staje się funkcjonowanie placówek obejmujących heterogeniczne grupy, zróżnicowane z uwagi na rodzaj i stopień niepełnosprawności, czy też poziom funkcjonowania osób wchodzących w ich skład. Zjawisko to wymusza konieczność odpowiedniego przygotowania pedagogów specjalnych. Tym samym wyodrębnia się przestrzeń do zaistnienia pedagogiki integracyjnej.

- Od wyodrębniania subdyscyplin z uwagi na rodzaj niepełnosprawności do budowania systematyki opartej na innych niż niepełnosprawność kryteriach klasyfikacyjnych. Innymi niż rodzaj niepełnosprawności wyznacznikami umożliwiającymi wyodrębnianie subdyscyplin w pedagogice specjalnej mogą być: etap życia, obszar aktywności osób niepełnosprawnych lub specyfika podejmowanych wobec tych osób działań. Rozwiązanie to legło u podstaw tworzenia takich subdyscyplin, jak: andragogika specjalna czy pedagogika specjalna wczesnego dzieciństwa [por. Stochmiałek 2005: 435-443; Eckert 1994: 11-23), a być może doprowadzi do wyodrębnienia kolejnych subdyscyplin, które zaznaczają już swoją obecność w przestrzeni pedagogiki specjalnej (pedagogika seksualności osób niepetnosprawnych, pedagogika pracy osób niepetnosprawnych, pedagogika twórczości osób niepetnosprawnych, pedagogika wczesnego wspomagania rozwoju dziecka niepetnosprawnego lub zagrożonego niepetnosprawnościa). Zastosowanie wspomnianych kryteriów (etap życia, obszar aktywności) pozwala zaakcento- 
wać, niezależnie od rodzaju niepełnosprawności, podobieństwa w zakresie właściwości i potrzeb rozwojowych, ogranicza ryzyko etykietowania przez pryzmat określonej niepełnosprawności [Parys 2011: 43]. Jednak niebezpieczeństwo naznaczania jest nadal realne poprzez ryzyko ograniczania obszaru zainteresowań subdyscypliny do problemów osób niepełnosprawnych. Obawa przed utratą tożsamości może prowadzić do izolowania się subdyscypliny poprzez wyznaczanie hermetycznych granic, marginalizowanie podobieństw przy nadmiernym eksponowaniu różnic.

Zakres działań podejmowanych w ramach pedagogiki specjalnej można opisywać odwołując się również do ich podmiotu, czyli osób, wokół których pedagogika specjalna koncentruje rozważania teoretyczne i z myślą o których opracowuje i uruchamia rozwiązania praktyczne. Wraz z upływem lat zmienia się podmiot pedagogiki specjalnej. Poszerza się grupa osób, wobec których dyscyplina ta kieruje swoje działania. Zmiany w tym zakresie przyjmują następującą postać:

- Od koncentracji na osobach funkcjonujących poniżej normy do najczęściej nominalnego włączania w obszar zainteresowań także osób powyżej normy [Firkowska-Mankiewicz, Szumski 2009: 323]. Należy przy tym zauważyć, iż w polskiej pedagogice specjalnej wyraźnie dominują zagadnienia dotyczące osób funkcjonujących poniżej normy rozwojowej.

- Od uwzględniania w działaniach rehabilitacyjnych tylko osób z wyraźną niepełnosprawnością (jednak taką, w przypadku której dostrzegano możliwość uzyskania pozytywnych efektów w działaniach usprawniających - „unormalnienia”, upodobnienia do osoby pełnosprawnej w jakości funkcjonowania) do objęcia uwagą również osób funkcjonujących w granicach normy, lecz zagrożonych niepełnosprawnością (osób wykazujących niewielkie zaburzenia oraz osób, w przypadku których szanse rehabilitacji wydają się być w znacznym stopniu ograniczone: niepełnosprawnych w stopniu głębokim, chorych terminalnie) $)^{3}$. Zaistniałą zmianę można wiązać ze wzrostem znaczenia przypisywanego profilaktyce, a także z większymi możliwościami podejmowania działań w tym zakresie. Nie bez znaczenia są również przeobrażenia w postrzeganiu możliwości rozwojowych osób z niepełnosprawnością.

- Od podejmowania działań skierowanych głównie na osoby z jednorodnymi niepełnosprawnościami (wyjątek stanowi grupa osób głuchoniewidomych) do pracy rehabilitacyjnej kierowanej również wobec osób wykazujących niepełnosprawności złożone.

\footnotetext{
Wśród zmian ilustrujących to zjawisko można wskazać pojawienie się w latach 60. XX w. w systemie edukacji szkół dla osób z niepełnosprawnością intelektualną w stopniu umiarkowanym lub znacznym (tzw. „szkół życia”), czy objęcie działaniami edukacyjnymi w 1997 roku dzieci i młodzieży z niepełnosprawnością intelektualną w stopniu głębokim.
} 
- Od uwzględniania osób z klasycznymi rodzajami niepełnosprawności do włączania w zakres zainteresowań pedagogiki specjalnej także osób, których funkcjonowanie odbiega od normy $\mathrm{z}$ uwagi na nieopisane wcześniej zespoły chorobowe. Zjawisko to należy m.in. wiązać z rozwojem medycyny, faktem pojawienia się grupy nowych nieopisanych wcześniej tzw. rzadkich zespołów chorobowych.

- Od zainteresowania okresem edukacji do podejmowania działań dotyczących całego biegu życia, od poczęcia aż do śmierci.

- Od koncentracji na osobie niepełnosprawnej do objęcia uwagą również jej otoczenia. Uwzględnianie kontekstu środowiskowego zmusza do kierowania działań także wobec rodzin osób niepełnosprawnych, profesjonalistów działających na rzecz tych osób, czy szerszego środowiska społecznego. Tym samym poszerza się zbiór podmiotów oddziaływań pedagogiki specjalnej.

Przeobrażenia dotykają również przedmiotu pedagogiki specjalnej-działań, jakie są podejmowane w jej obszarze. Wektory tych przeobrażeń przyjmują następującą postać:

- Od diagnozy negatywnej, uwzględniającej wyłącznie uszkodzenia, braki, ograniczenia tkwiące w osobie i jej środowisku do łączenia diagnozy negatywnej i pozytywnej, respektując również zasoby podmiotu i jego otoczenia.

- Od diagnozy nozologicznej, podkreślającej defekt i jego konsekwencje do diagnozy funkcjonalnej, akcentującej także zachowane możliwości, mającej na celu zaplanowanie pracy z daną osobą.

- Od prób odnalezienia odpowiedzi na pytanie "Jak usunąć niepełnosprawność?" do podejmowania refleksji nad pytaniem "Jak dobrze funkcjonować z niepełnosprawnością?" O ile pierwsze pytanie wskazuje na brak akceptacji niepełnosprawności, a w związku z tym prowadzi do koncentracji przede wszystkim na działaniach naprawczych, o tyle w drugim pytaniu można dostrzec dążność do zaakceptowania niepełnosprawności, która skutkuje poszerzeniem repertuaru działań rehabilitacyjnych o oddziaływania wzmacniające, dynamizujące rozwój.

- Od koncentrowania się na różnicach, „uspecjalnianiu” oddziaływań i osób nimi objętych do ograniczania wymienionych działań poprzez eksponowanie tego, co wspólne. Tendencję tę można odnaleźć w funkcjonowaniu jednej podstawy programowej dla niemal wszystkich uczniów ${ }^{4}$ oraz realizacji nauczania inkluzyjnego.

- Od „unormalniania” osoby niepełnosprawnej do wprowadzania w życie szeroko pojętej normalizacji. „Unormalnianie” rozumiane jest jako próba "naprawienia", dopasowania osoby niepełnosprawnej do otoczenia, do wzorca, jakim

$\overline{4}$ Jedynie uczniowie z umiarkowaną i znaczną niepełnosprawnością intelektualną realizują odrębną podstawę programową. 
miałby być sposób funkcjonowania osób pełnosprawnych. Tego rodzaju postępowanie zostaje zastąpione przez działania mające na celu wywołanie zmian nie tylko w osobie niepełnosprawnej, ale i w otoczeniu. Dopuszcza się różnorodność wprowadzanych zmian, nie są one narzucane w dyrektywny sposób, bowiem podstawą normalizacji jest poszanowanie prawa do odmienności, a dobrostan osoby z niepełnosprawnością staje się ważnym wyznacznikiem podejmowanych działań.

- Od zakładania granic rozwojowych do niestawiania punktów granicznych, uznania, że niepełnosprawność nie jest ostatecznym wyznacznikiem możliwości osób, które jej doświadczają. Wyraźnym przykładem tej zmiany jest odejście od klasyfikacji opartej na kryterium wyuczalności i wychowalności, zakładającej z góry nieskuteczność oddziaływań edukacyjnych lub wychowawczych w przypadku osób z głębszym lub głębokim stopniem niepełnosprawności intelektualnej.

- Od podejmowania wobec osób z głębokim stopniem niepełnosprawności jedynie działań opiekuńczych [por. Sękowska 1982] do poszerzania wachlarza oddziaływań rehabilitacyjnych bez względu na prawdopodobieństwo spodziewanych rezultatów.

- Od stosowania rozwiązań izolacyjnych, segregacyjnych po działania integracyjne i włączające w każdym obszarze życia.

- Od działań odnoszących się tylko do kwestii kształcenia dzieci i młodzieży do uwzględniania aktywności charakterystycznych dla różnych etapów i sfer życia (np. aktywność zawodowa, rekreacja, twórczość, seksualność).

- Od infantylizacji procesu rehabilitacji, polegającej na podejmowaniu działań nieadekwatnych do wieku życia osoby niepełnosprawnej do projektowania działań rehabilitacyjnych uwzględniających nie tylko faktyczny poziom funkcjonowania tych osób, ale również ich wiek życia i potrzeby z nim związane.

- Od modelu interwencji skupionego na osobie z niepełnosprawnością do objęcia oddziaływaniami również jej otoczenia, postępowania według założeń modelu ekologiczno-systemowego.

- Od uprzedmiotowienia osoby niepełnosprawnej do podmiotowego jej traktowania, tworzenia warunków pozwalających na społeczną partycypację. Osoba z niepełnosprawnością staje się równoprawnym uczestnikiem działań, współdecyduje o sobie, wyraża własne opinie. Przykładem tego rodzaju tendencji może być dążenie do realizowania diagnozy o charakterze interakcyjnym. 


\section{Zmiany w podejściu badawczym pedagogiki specjalnej}

Wzrasta zaawansowanie teoretyczne i metodologiczne pedagogiki specjalnej jako nauki. Należy jednak zwrócić uwagę, iż pedagogika specjalna nigdy nie dysponowała odrębną metodologią, a zatem wspomniany postęp zachodzi przede wszystkim dzięki adaptacji dokonań innych dyscyplin wiedzy (m.in. psychologii, socjologii, medycyny, antropologii).

Kierunki zmian $\mathrm{w}$ podejściu badawczym pedagogiki specjalnej są następujące:

- Od mających źródła w pozytywizmie prób obiektywizacji opisu rzeczywistości, wskazywania na uniwersalne mechanizmy wyznaczające funkcjonowanie do respektowania niepowtarzalności ludzkich losów w złożonych relacjach ze światem.

- Od perspektywy, w której osoba niepełnosprawna opisywana jest "z zewnątrz" do respektowania subiektywnego stanowiska osób niepełnosprawnych, odwoływania się do ich poglądów, doświadczeń, wsłuchiwania się w ich głosy.

- Od dominacji podejścia ilościowego do akcentowania znaczenia podejścia jakościowego [Chodkowska 1993; Borowska-Beszta 2005; Sekułowicz 2005; Rzeźnicka-Krupa 2007; Cytowska 2012; Kopeć 2013], w oparciu o działania wykorzystywane wcześniej wyłącznie w praktyce pedagogicznej, co skutkuje koegzystencją różnych rozwiązań badawczych, zróżnicowaniem mapy podejść metodologicznych [Krause 2010; Sadowska 2010: 221-232].

- Od trzymania się ściśle wytyczonych granic zainteresowań badawczych pedagogiki, koncentracji na problematyce wychowania i nauczania do poszerzania problematyki badawczej poprzez wchodzenie na obszary niezwiązane z edukacją, a nawet do upłynnienia wcześniej wyznaczonych granic, wymiany pól zainteresowań poznawczych między różnymi dyscyplinami nauki. Niewątpliwie „przekraczanie granic dyscyplin naukowych jest twórcze i pożyteczne, lecz dialog z naukami pogranicznymi nie może wytwarzać sytuacji nieprzejrzystej przyszłości w zakresie jej tożsamości naukowo-badawczej" [Dykcik 1999: 24]. Takie „uchylanie się od zakreślania jasnych granic dyscypliny” [Sadowska 2017: 35] stanowi wręcz zagrożenie dla jej rozwoju.

- Jeszcze jedna, dająca się zauważyć tendencja opisująca zmiany w podejściu badawczym pedagogiki specjalnej dotyczy intensyfikacji badań interdyscyplinarnych. Tego rodzaju badania obecnie są prowadzone częściej, zespoły badawcze stają się coraz bardziej zróżnicowane, biorąc pod uwagę reprezentowaną dziedzinę nauki, ośrodek, z jakiego wywodzą się badacze. Coraz powszechniejsze stają się badania międzynarodowe. 


\section{Zmiany dotyczące terminologii $\mathrm{w}$ pedagogice specjalnej}

Przeobrażenia w pedagogice specjalnej ujawniają się również w obszarze stosowanej terminologii. Jedna z dostrzegalnych zmian dotyczy narastającej liczby terminów. Pojawianie się nowych określeń (np. dziecko zagrożone niepetnosprawnościa) wynika z potrzeby nazywania nowych zjawisk ujawniających się na skutek poszerzania zakresu zainteresowań pedagogiki specjalnej. Innym powodem rozrastania się zbioru terminów jest wprowadzanie nowych, nieznanych dotychczas określeń w miejsce już istniejących. Nie dzieje się to jednak z natychmiastowym skutkiem. Być może z powodu przyzwyczajenia, przywiązania do tradycji językowej lub też braku akceptacji dla nowych rozwiązań leksykalnych dochodzi do sytuacji pluralizmu terminologicznego, który wyraża się w stosowaniu więcej niż jednego terminu na określenie tego samego zjawiska (osoba niepełnosprawna, osoba z niepetnosprawnościa, osoba sprawna inaczej, osoba z ograniczeniami sprawności; pedagogika osób upośledzonych umysłowo, pedagogika osób niepełnosprawnych intelektualnie, oligofrenopedagogika).

Równocześnie należy zwrócić uwagę na zjawisko zmian znaczeniowych, jakie wiąże się ze stosowaniem tego samego terminu w różnym czasie. Termin używany współcześnie nie musi mieć tożsamego znaczenia z terminem stosowanym w przeszłości. Np. obecnie pedagog specjalny to nie tylko osoba pełniąca funkcje nauczyciela w szkole specjalnej; pedagogika lecznicza to tylko jeden działów pedagogiki specjalnej, a nie - jak w przeszłości - nazwa całej dyscypliny; kształcenie specjalne to proces realizowany nie tylko w szkołach specjalnych. Zmiany te odzwierciedlają przeobrażenia zachodzące w obszarze pedagogiki specjalnej. Należy zaznaczyć, że mogą być powodem wysuwania błędnych wniosków, gdy znaczenia dzisiaj przypisywane stosowanym terminom będą odnoszone do sytuacji z przeszłości.

Charakterystyczne w coraz większym stopniu dla języka pedagogiki specjalnej staje się również wyczulenie na kwestie terminologiczne. O doborze i stosowaniu określonych słów, poza dbałością o jasność przekazu, decyduje dążenie do używania określeń, które nie naznaczają, „nie ranią”, nie budzą negatywnych skojarzeń. W ten sposób daje znać o sobie wiara w siłę sprawczą języka, wyrażająca się w próbach znalezienia terminów mogących ukryć lub uwypuklić dany aspekt rzeczywistości. W tym postępowaniu można upatrywać z jednej strony manifestacji nadwrażliwości, swoistej fobii terminologicznej, a z drugiej strony większej dbałości o humanizację stosowanej terminologii. Wyczulenie na kwestie terminologiczne wyraża się również w doborze sformułowań, które nie akcentują niepełnosprawności, stawiają osobę przed niepełnosprawnością (osoba z niepełnosprawnością zamiast osoba niepetnosprawna), podkreślają przy tym podmiotowość 
osoby określanej w taki sposób. Działania tego rodzaju mogą wzmacniać świadomość znaczenia stosowanych słów, modelujących odbiór społeczny, a także kształtować $w$ ramach swoiście pojmowanej inżynierii słownej przestrzeń do funkcjonowania osób z niepełnosprawnością.

Język współczesnej pedagogiki specjalnej staje się w coraz większym stopniu zunifikowany, następuje upodobnienie polskiej i zagranicznej nomenklatury (empowerment, inkluzja). Ta globalizacja terminologiczna ma swoje źródła w coraz doskonalszym przepływie informacji, procesach globalnej komunikacji, respektowaniu tych samych ponadpaństwowych aktów prawnych. Rodzi to równocześnie niebezpieczeństwo bezmyślnego stosowania kalek językowych, powielania gotowych, niekoniecznie adekwatnych na danym gruncie rozwiązań.

W przestrzeni współczesnej pedagogiki specjalnej coraz większego znaczenia nabierają dyskusje terminologiczne, podczas których ujawniają się zarówno argumenty emocjonalne, jak i arbitralne oraz merytoryczne. Należy podkreślić, iż jedynie obecność argumentów merytorycznych może pozwolić na faktyczny rozwój dyscypliny (Pańczyk 2006: 66). Trzeba zauważyć, iż w dysputach poświęconych terminologii uwzględniana jest pomijana uprzednio perspektywa osób z niepełnosprawnością, a ponadto coraz częściej osoby te stają się aktywnymi uczestnikami wspomnianych dyskusji. Przykładem działań respektujących stanowisko osób z niepełnosprawnością w zakresie kwestii terminologicznych jest wprowadzenie do słownika określenia Głuchy (pisanego z wielkiej litery), które w założeniu ma uwidocznić odmienność kulturową tej grupy.

\section{Zakończenie}

Zaprezentowane $\mathrm{w}$ niniejszym tekście analizy z konieczności zawierają uproszczenia, stanowią jedynie szkic zasadniczych tendencji dających znać o sobie $\mathrm{w}$ przeobrażeniach zachodzących $\mathrm{w}$ polskiej pedagogice specjalnej. Należy zauważyć, że omawiane zmiany nie są jednoznaczne, nie przebiegają w prostoliniowy, jednokierunkowy sposób. Dynamika tych zmian nie jest jednakowa, bywa że po okresie postępu następuje czas zastoju, a nawet regres. Często przyczyny oraz efekty zachodzących przeobrażeń sprzęgają się ze sobą, powiązania między nimi mają charakter cyrkularny.

Podstawowym czynnikiem warunkującym opisane zmiany jest reinterpretacja znaczeń przypisywanych niepełnosprawności. W syntetycznym ujęciu ilustruje ją droga od medycznego, poprzez społeczny do uniwersalnego (biopsychospołecznego) modelu niepełnosprawności. Efektem przeobrażeń w sposobie widzenia człowieka doświadczającego niepełnej sprawności jest: 
- Ujmowanie człowieka w holistyczny sposób, postrzeganie go w całościowy sposób, aprobata przekonania, że niepełnosprawność to tylko jeden z wymiarów funkcjonowania. Takie ujęcie zastąpiło przeważający wcześniej sposób postrzegania osoby tylko poprzez pryzmat niepełnosprawności traktowanej jako dominanta w psychofizycznym profilu człowieka.

- Postrzeganie niepełnosprawności jako cechy względnej, związanej z jakością i charakterem relacji jednostki i społeczeństwa, w odróżnieniu od wcześniej obowiązującego sposobu widzenia w niepełnosprawności cechy istniejącej bez względu na kontekst funkcjonowania osoby.

- Traktowanie niepełnosprawności jako uniwersalnej cechy ludzkiego doświadczenia (każdy w większym bądź mniejszym stopniu w biegu swojego życia doświadcza niepełnosprawności) zastępujące dychotomiczne postrzeganie społeczeństwa wyrażające się w podziale na grupy osób pełnosprawnych i niepełnosprawnych.

- Akceptacja niepełnosprawności, postrzeganej jako rodzaj innej jakości, która ma prawo taką pozostać, nie jest traktowana jako przeszkoda, którą trzeba przezwyciężyć, defekt, który wymaga naprawy.

- Interpretacja niepełnosprawności w kategoriach zadania, wyzwania budzącego aktywność, bodźca zachęcającego do twórczego wysiłku, nie zaś jako niemożliwej do pokonania trudności, która usprawiedliwia bierność.

- Postrzeganie niepełnosprawności jako zjawiska dynamicznego, charakteryzującego się zmiennością $\mathrm{w}$ czasie, zastępujące fatalistyczne traktowanie niepełnosprawności jako cechy stałej.

- Stopniowo coraz większa dążność do uznawania i eksponowania praw, a z czasem i obowiązków osób z niepełnosprawnością.

- Równouprawnienie wyrażające się w możliwie najpełniejszym zrównaniu w prawach i obowiązkach wszystkich osób, niezależnie od poziomu ich sprawności, eliminujące konieczność tworzenia odrębnych praw i obowiązków dla osób z niepełnosprawnością.

- Uznanie i respektowanie prawa osób niepełnosprawnych do samostanowienia oraz spostrzeganie tych osób jako równorzędnych partnerów w procesie rehabilitacji, zastępujące paternalistyczne traktowanie osób niepełnosprawnych, wyrażające się m.in. poprzez podejmowanie decyzji w ich imieniu.

- Postrzeganie osoby niepełnosprawnej jako dysponującej zasobami pozwalającymi przyjmować rolę dawcy, nie zaś wyłącznie jako biorcy w relacjach społecznych.

Odnotowane w obszarze polskiej pedagogiki specjalnej zmiany nie są gwałtowne, mają charakter ewolucyjny [Firkowska-Mankiewicz, Szumski 2009: 320-321]. Przyczyn tego stanu rzeczy można upatrywać we wspólnocie formacji naukowej polskich pedagogów specjalnych zgodnie powołujących się na poglądy Marii 
Grzegorzewskiej. Opracowany przez nią zespół założeń teoretyczno-metodologicznych ma charakter ogólny, w związku z czym odznaczają się one ponadczasowością i uniwersalizmem. Takie myśli jak „,nie ma kaleki, jest człowiek”, „kkażdy człowiek ma prawo do miejsca w społeczeństwie i osobistego szczęścia”, „każdy człowiek, poza piętą achillesową ma punkt archimedesowy" mogą stanowić inspirację do działań podejmowanych również współcześnie.

Analiza zaprezentowanych zmian prowadzi do generalnej konstatacji, iż stałym elementem dla pedagogiki specjalnej, bez względu na upływający czas, jest różnie rozumiana i realizowana troska o osobę niepełnosprawną. Należy jednak zaznaczyć, iż nie jest to szczególny wyróżnik pedagogiki specjalnej, gdyż troska o człowieka właściwa jest również innym naukom pedagogicznym. Co więcej, zmniejsza się dystans między sposobami zabezpieczania potrzeb osób pełnosprawnych i niepełnosprawnych, zaciera się granica między tymi grupami osób, coraz częściej niepełnosprawność jest eksponowana wtedy, gdy jest to konieczne, zauważana i akcentowana na tyle, "na ile pomijanie tego zjawiska mogłoby utrudnić funkcjonowanie osobie niepełnosprawnej i byłoby przejawem dyskryminacji" [Parys 2012: 126]. Staje się jedną z możliwych różnic indywidualnych, wydaje się coraz mniej widoczna, zaczyna być traktowana jako naturalny element otaczającej rzeczywistości.

Dodatkowo, inne dziedziny wiedzy: psychologia, socjologia, etnologia coraz wyraźniej włączają w zakres swoich działań problematykę dotyczącą osób niepełnosprawnych. Pedagogika specjalna natomiast wkracza na obszary zarezerwowane dotąd dla innych nauk. Tym samym mniej wyraźne stają się granice określające zakres oddziaływań pedagogiki specjalnej.

Zaprezentowane rozważania prowokują do postawienia pytań: Czy pedagogika specjalna jest wciąż potrzebna? Jak należy ją współcześnie definiować w świetle przedstawionych zmian? Na czym ma polegać jej specyfika? Co powinno stanowić istotę pedagogiki specjalnej? Jaki powinien być jej zakres, jaki charakter mają przyjąć jej oddziaływania?

Zasadność istnienia pedagogiki specjalnej potwierdza obecność osób wykazujących zapotrzebowanie na wsparcie. Dostrzegane zmiany zaświadczają, iż pedagogika specjalna pozostając pedagogiką specjalną realizującą zadania nastawione na wspieranie, staje się w coraz większym stopniu pedagogiką różnic indywidualnych [Firkowska-Mankiewicz, Szumski 2009: 324], pedagogiką emancypacyjną [Krause 2009: 15], a wreszcie pedagogiką poszukiwania możliwości sukcesu [Dykcik 1999: 22]. 


\section{Bibliografia}

Binnebesel J. (2013), Tanatopedagogika w doświadczeniu wielowymiarowości człowieka i śmierci, Wydawnictwo Adam Marszałek, Toruń.

Borowska-Beszta B. (2005), Etnografia dla terapeutów (pedagogów specjalnych). Szkice metodologiczne, Oficyna Wydawnicza „Impuls”, Kraków.

Chodkowska M. (1993), Kobieta niepetnosprawna. Socjopedagogiczne problemy postaw, Wydawnictwo UMCS, Lublin.

Cytowska B. (2012), Trudne drogi adaptacji, Oficyna Wydawnicza „Impuls”, Kraków.

Dykcik W. (1999), Pedagogika specjalna w sytuacji aktualnych zagrożeń i wyzwań [w:] Pedagogika specjalna wobec zagrożeń i wyzwań XXI wieku, J. Pańczyk, W. Dykcik (red.), WSPS, Warszawa, UAM, Poznań, s. 21-43.

Eckert U. (1994), Wspótczesne zadania pedagogiki specjalnej w Polsce [w:] Człowiek niepetnosprawny. Problemy autorealizacji i społecznego funkcjonowania. Charisteria dla Profesor Zofii Sękowskiej, M. Chodkowska (red.), Wydawnictwo UMCS, Lublin, s. 11-23.

Firkowska-Mankiewicz A., Szumski G. (2009), Pedagogika specjalna i system kształcenia osób z niepetnosprawnościami w Polsce [w:] D.D. Smith, Pedagogika specjalna, t. 2, Wydawnictwo Naukowe PWN, Warszawa, s. 319-346.

Jugowar B. (2005), Pedagogika osób odmiennych somatycznie [w:] Pedagogika specjalna, W. Dykcik (red.), Wydawnictwo UAM, Poznań, s. 231-240.

Kopeć D. (2004), Kondycja polskiego szkolnictwa specjalnego - analiza wybranych problemów [w:] Dyskursy pedagogiki specjalnej 3. Rehabilitacja, opieka i edukacja specjalna w perspektywie zmiany, C. Kosakowski, A. Krause (red.), Wydawnictwo UWM, Olsztyn, s. 86-92.

Kopeć D. (2013), Rzeczywistość (nie)edukacyjna osoby z głęboka niepetnosprawnościa intelektualna, Wydawnictwo Naukowe UAM, Poznań.

Krause A. (2009), Teoretyczne i empiryczne problemy pedagogiki specjalnej. Zarys obszarów badawczych, "Niepełnosprawność”, nr 1, s. 9-24.

Krause A. (2010), Wspótczesne paradygmaty pedagogiki specjalnej, Oficyna Wydawnicza „Impuls", Kraków.

Lipkowski O. (1981), Pedagogika specjalna. Zarys, PWN, Warszawa.

Pańczyk J. (2004), "Quo vadis" edukacjo specjalna? [w:] Dyskursy pedagogiki specjalnej 3. Rehabilitacja, opieka i edukacja specjalna w perspektywie zmiany, C. Kosakowski, A. Krause (red.), Wydawnictwo UWM, Olsztyn, s. 13-17.

Pańczyk J. (2006), Upośledzenie umysłowe czy niepetnosprawność intelektualna [w:] Forum Pedagogów Specjalnych XXI wieku, t. 7, J. Pańczyk (red.), Hamal, Łódź, s. 65-75.

Parys K. (2011), Zakres oddziaływań wspótczesnej pedagogiki specjalnej na tle dotychczasowych przemian, „Niepełnosprawność", nr 5, s. 22-50.

Parys K. (2012), Przestrzeń społeczna [w:] S. Olszewski, K. Parys, M. Trojańska, Przestrzenie życia osób z niepetnosprawnościa, Wydawnictwo Naukowe UP, Kraków, s. 89-135.

Parys, Olszewski (2018), Quo vadis, special pedagogy? Reflections in the context of the Polish experience [w:] Teória a praxeológia výchovnej a komplexnej rehabilitácie. Zbornik vedeckých príspevkov, T. Harčaríková, J. Lopúchová (red.), Wydawnictwo MSD, Brno, s. 294-307.

Pedagogika specjalna (2005), red. W. Dykcik, Wydawnictwo UAM, Poznań.

Pilecka W. (2005), Pedagogika osób z trudnościami w uczeniu się [w:] Pedagogika specjalna, W. Dykcik (red.), Wydawnictwo UAM, Poznań, s. 241-262. 
Pilecka W., Pilecki J. (1993), Quo vadis wychowanie dzieci upośledzonych umystowo [w:] Roczniki Pedagogiki Specjalnej, t. 4, J. Pańczyk (red.), Wydawnictwo WSPS, Warszawa, s. 26-37.

Piotrowski E. (2005), Pedagogika dzieci zdolnych i uzdolnionych [w:] Pedagogika specjalna, W. Dykcik (red.), Wydawnictwo UAM, Poznań, s. 327-343.

Rzeźnicka-Krupa J. (2007), Komunikacja - edukacja - społeczeństwo. O dyskursie dzieci z niepetnosprawnością intelektualna, Oficyna Wydawnicza „Impuls”, Kraków.

Sadowska S. (2004), Przemiany w edukacji specjalnej w perspektywie paradygmatu oporu [w:] Rehabilitacja, opieka i edukacja specjalna w perspektywie zmiany, Dyskursy Pedagogiki Specjalnej 3, C. Kosakowski, A. Krause (red.), Wydawnictwo UWM, Olsztyn, s. 80-85.

Sadowska S. (2010), W poszukiwaniu potencjału uprawiania pedagogiki specjalnej-perspektywa naukoznawcza i metodologiczna [w:] Pedagogika specjalna - tak wiele pozostaje tajemnica, S. Przybyliński (red.), Wydawnictwo UWM, Olsztyn, s. 221-232.

Sadowska S. (2012), W kręgu spięć, rozterek i potencjału uprawiania pedagogiki specjalnej, „Szkoła Specjalna", nr 4, s. 260-268.

Sadowska S. (2017), Bez konturu? O potrzebie samoświadomości dyscyplinarnej pedagogiki specjalnej, „Niepełnosprawność”, nr 27, s. 24-37.

Sekułowicz M. (2005), Nauczyciele szkolnictwa specjalnego wobec zagrożenia wypaleniem zawodowym. Analiza przypadków, Wydawnictwo Naukowe DSWE TWP, Wrocław.

Sękowska Z. (1982). Pedagogika specjalna. Zarys, PWN, Warszawa.

Stochmiałek J. (2005), Andragogika specjalna [w:] Pedagogika specjalna, W. Dykcik (red.), Wydawnictwo UAM, Poznań, s. 435-443.

Zaorska M. (2011), Quo vadis szkolnictwo specjalne?, „Wychowanie na co Dzień”, nr 12, s. 4-9. 